\title{
GEOMATIC METHODS APPLIED TO THE CHANGE STUDY OF THE LA PAÚL ROCK GLACIER, SPANISH PYRENEES
}

\author{
A. Martínez-Fernández ${ }^{1,}$ *, E. Serrano ${ }^{1}$, J. J. Sanjosé ${ }^{2}$, M. Gómez-Lende ${ }^{3}$, A. Pisabarro ${ }^{1}$, M. Sánchez ${ }^{2}$ \\ ${ }^{1}$ Dept. of Geography, University of Valladolid, Valladolid, Spain - (adrian.martinez, alfonso.pisabarro)@uva.es, \\ serranoe@fyl.uva.es \\ ${ }^{2}$ Dept. of Graphic Expression, Polytechnic School, University of Extremadura, Cáceres, Spain - (jjblasco, msf)@ unex.es \\ ${ }^{3}$ GIR PANGEA, University of Valladolid, Valladolid, Spain - manuelglende@ gmail.com
}

KEY WORDS: Rock Glacier, Periglacial Processes, Pyrenees, TLS, GNSS

\begin{abstract}
:
Rock glaciers are one of the most important features of the mountain permafrost in the Pyrenees. La Paúl is an active rock glacier located in the north face of the Posets massif in the La Paúl glacier cirque (Spanish Pyrenees). This study presents the preliminary results of the La Paúl rock glacier monitoring works carried out through two geomatic technologies since 2013: Global Navigation Satellite System (GNSS) receivers and Terrestrial Laser Scanning (TLS) devices. Displacements measured on the rock glacier surface have demonstrated both the activity of the rock glacier and the utility of this equipment for the rock glaciers dynamic analysis. The glacier has exhibited the fastest displacements on its west side (over $35 \mathrm{~cm} \mathrm{yr}^{-1}$ ), affected by the Little Ice Age, and frontal area (over $25 \mathrm{~cm} \mathrm{yr}^{-1}$ ). As an indicator of permafrost in marginal environments and its peculiar morphology, La Paúl rock glacier encourages a more prolonged study and to the application of more geomatic techniques for its detailed analysis.
\end{abstract}

\section{INTRODUCTION}

The high mountain processes related to the cryosphere respond in a clear way to the climatic variability. A prolonged global study of high altitude ice masses or frozen bodies, such as glaciers, rock glaciers or ice patches, can contribute to the global modelling of effects such as climate change. In this sense, the control of the dynamics of these ice landforms becomes a fundamental part. Knowing their physical variations, and being able to relate them to other studies, may allow us to understand why these bodies behave this way. Depending on local (e.g., topography, location) and global (e.g., climate) factors, these dynamics or rates of change are affected to a greater or lesser extent.

In the case of ice landforms in high temperate mountains, such as the Pyrenees, the response to these climatic variations is usually particularly fast. Small inter-annual fluctuations in precipitation and temperature especially affect their dynamics. This influence seems to be due to the limited extension and the situation in latitude and altitude of these ice bodies (LópezMoreno et al., 2006).

Among these ice landforms, the Pyrenean rock glaciers are clear indicators of the existence of mountain permafrost. Their presence in marginal environments makes them sensitive to environmental changes, making them effective morphoclimatic geo-indicators. Therefore, in order to classify them as active and use them as permafrost indicators, it is essential to verify their movement and the existence of ice inside them. (Serrano et al., 1999, 2006, 2010).

The application of geomatic techniques is especially useful for the control of the dynamics of rock glaciers due to its versatility and limited impact on glaciers (Sanjosé et al., 2014). Periodic use of these techniques can make it possible to determine displacements on their surface, as well as variations in their volume.

This study presents the application of two geomatic techniques (i.e., GNSS and terrestrial LiDAR) for the analysis of the dynamics of the La Paúl rock glacier since summer 2013. In this way, the preliminary results of the displacements and deformation rates of the rock glacier are shown.

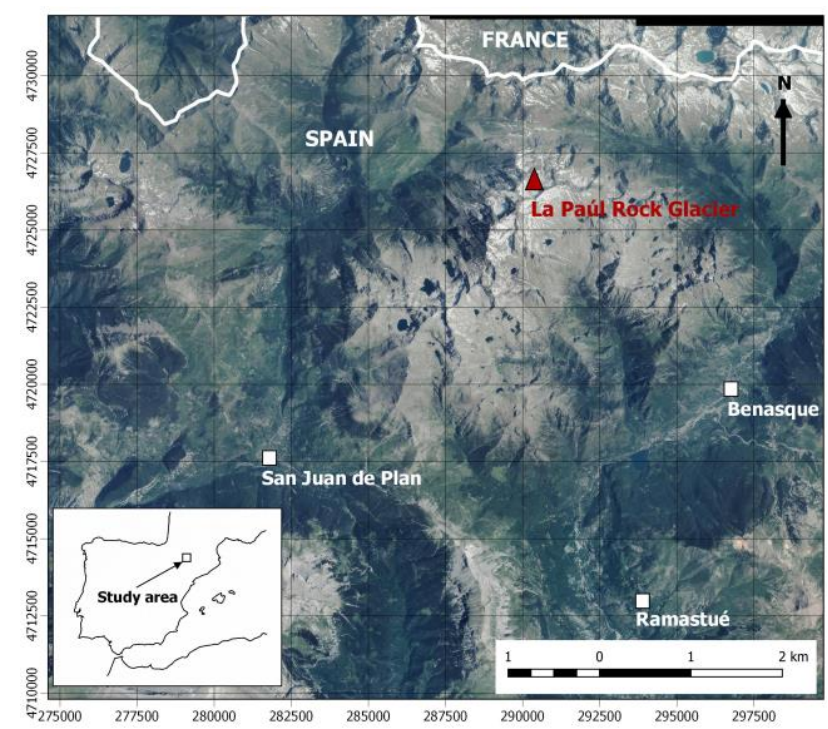

Figure 1. Location of La Paúl rock glacier (ETRS89 / UTM $31 \mathrm{~N}$; orthophoto from PNOA 2015 CC-BY scne.es)

\footnotetext{
* Corresponding author
} 


\section{LA PAÚL ROCK GLACIER}

In the Posets massif (Spanish Pyrenees) are located the glacier and the rock glacier of La Paúl (Lat. 42 $39^{\prime} 40^{\prime \prime}$ N/ Long. $0^{\circ} 26^{\prime} 34^{\prime \prime} \mathrm{E}$; Fig. 1). The rock glacier is composed of periglacial debris with a tongue of $400 \mathrm{~m}$ length, extended between $2830 \mathrm{~m}$ and $2950 \mathrm{~m}$ of altitude, which has been eroded on its NW edge during the Little Ice Age (LIA) (Serrano and Martín-Moreno, 2018; Fig. 2 and Fig. 3). Thermal ground records, basal temperature measurements of the snowpack and electrical tomographies have shown the presence of frozen ground in the rock glacier (Serrano et al., 2001; Lugon et al., 2004; GonzálezGarcía, 2014).

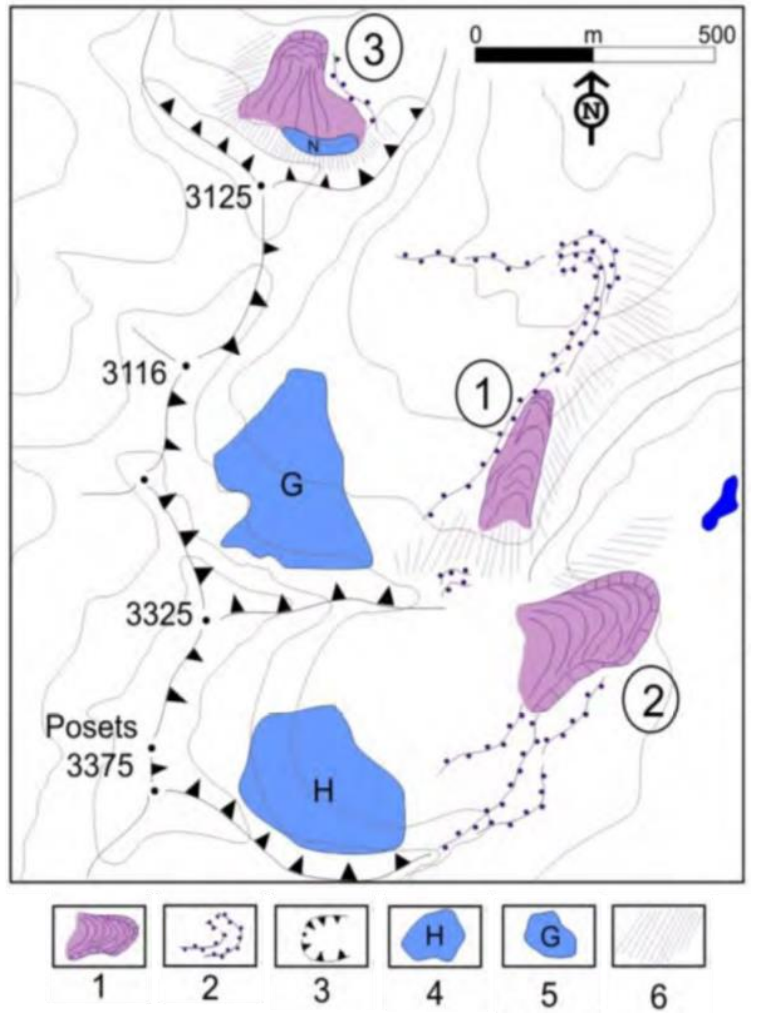

Figure 2. Geomorphological sketch of the La Paúl surroundings. Inside a circle: the rock glaciers of La Paúl (1), Posets (2) and Los Gemelos (3). Legend: 1, rock glacier. 2, moraines. 3 , cirque. 4 , ice patches. 5 , glacier. 6 , slope debris

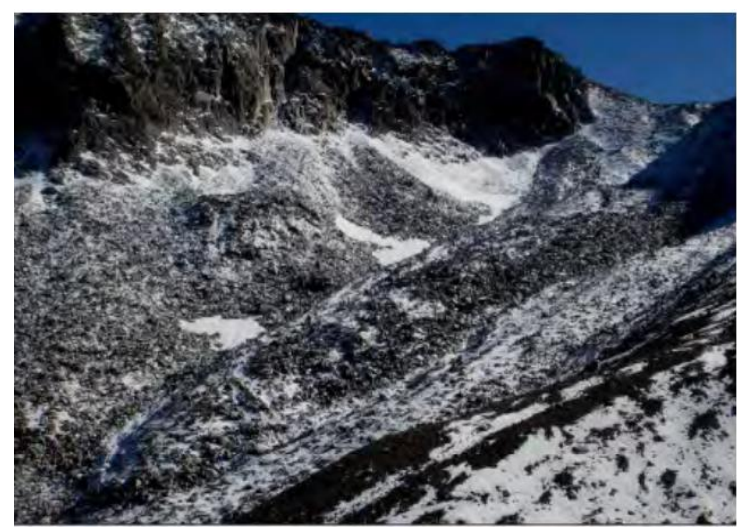

Figure 3. La Paúl rock glacier

\section{METHODS}

So far, two geomatic techniques have been combined in the rock glacier:

- Global Navigation Satellite System (GNSS): Geolocation of 20 steel rods distributed along the surface of the rock glacier using GNSS-RTK techniques (Fig. 4). Between 2013 and 2018 annual measurements have been made with Leica GPS1200 receivers, obtaining mean accuracies of about $2 \mathrm{~cm}$ in the 20 points.

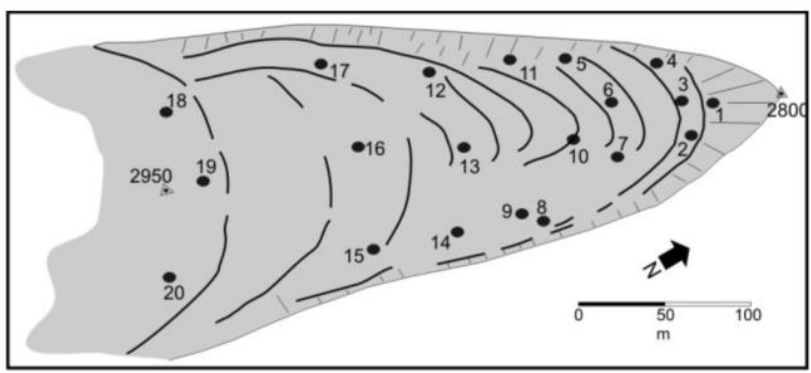

Figure 4. Rods location for GNSS-RTK measurements on the rock glacier

- Terrestrial Laser Scanner (TLS): scans of the entire body of the glacier (Fig. 5 and Fig. 6) through the phase-shift scanner Faro Focus3D X330. Since the 2016 annual campaign, 3D surface models of the rock glacier and surroundings have been generated. Targets located through the GNSS receivers have permitted to georeferencing an average of 8 scans and approximately 150 million registered points in the last three years. Mean registration errors did not exceed $2 \mathrm{~cm}$ while referencing errors remained below $5 \mathrm{~cm}$.

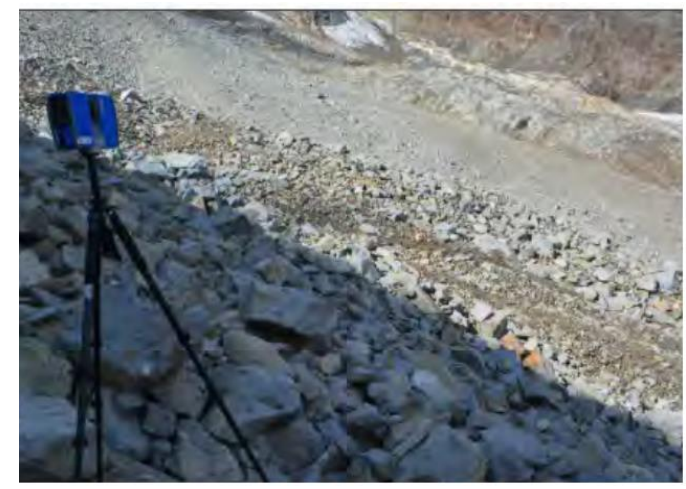

Figure 5. One of the TLS placements on the east side of the La Paúl rock glacier

Leica Geo Office software has been used for the GPS data treatment, while point clouds were generated through the 3D processing software Faro Scene. Surface displacements estimation over the last five years (all of them measured with GPS and the past three years with TLS) has been determined by the annual correlation of the rods coordinates and by $3 \mathrm{D}$ comparison between the clouds. 


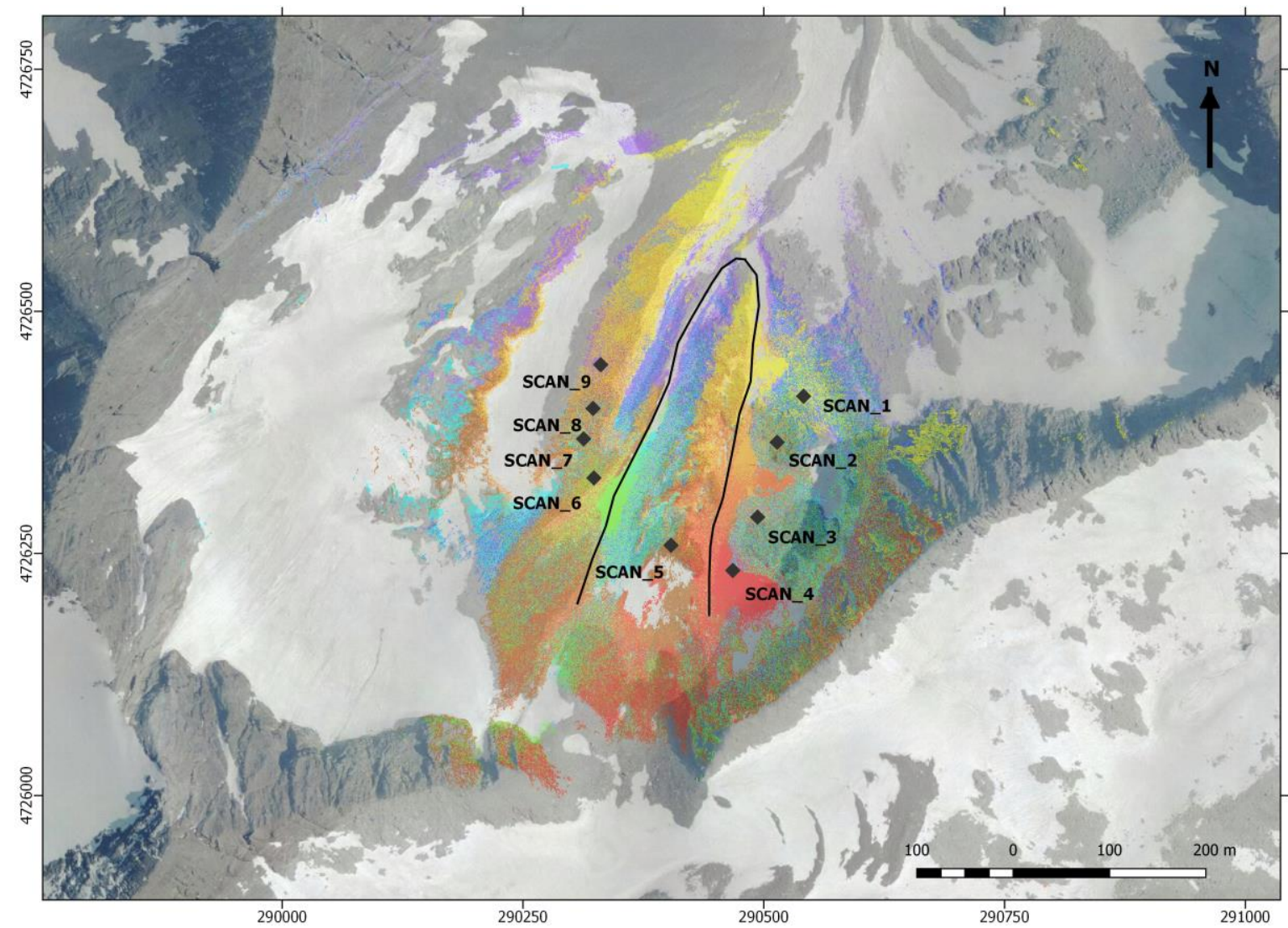

Figure 6. Point clouds obtained by TLS on the rock glacier, 2018. Colours correspond to the different scans (ETRS89 / UTM 31N; orthophoto from PNOA 2015 CC-BY scne.es)

This 3D comparison has been carried out through the Cloud to Cloud algorithm of the CloudCompare software (CloudCompare 2.9, 2018), using local modelling strategies. When no local model is used, the algorithm computes the differences between two point clouds (i.e., reference cloud and compared cloud) by measuring the (Euclidean) distance between the nearest points of each cloud (i.e., nearest neighbour distance). Due to the different locations where the scans were placed, and the movement of the rock glacier itself, the areas without data do not coincide between consecutive years. For this reason, distances have been calculated using local models. This strategy allows a local model to be computed around each point of the reference cloud to generate an approximation of the actual surface. The local model used is based on the Delaunay 's triangulation and has been applied over a radius of $50 \mathrm{~cm}$ around the points.

\section{PRELIMINARY RESULTS}

Based on GNSS measurements on the 20 rods (six measurement campaigns, five years of comparisons), mean movements of $0.32 \mathrm{~m}$ in planimetry and $-0.2 \mathrm{~m}$ in altimetry were registered since 2013 (Table 1). Although the average of the 6-year measured coordinates is similar in different parts of the glacier, occasional exceptions appeared. The west edge of the rock glacier showed particularly active years with rods movements of $30-45 \mathrm{~cm} \mathrm{yr}^{-1}$, which contrasted with the occasional small displacements in the east edge $\left(15-40 \mathrm{~cm} \mathrm{yr}^{-1}\right)$. The front registered the major changes $\left(45-65 \mathrm{~cm} \mathrm{yr}^{-1}\right)$, although with a very irregular distribution. Altogether, the variations in the surface showed a wave displacement related to the slope changes.

\begin{tabular}{cccc}
\hline Punto & $\mathbf{X}(\mathbf{c m})$ & $\mathbf{Y}(\mathbf{c m})$ & $\mathbf{Z}(\mathbf{c m})$ \\
\hline 1 & 10,2 & 29,7 & $-15,2$ \\
2 & 13,9 & 36,6 & $-17,8$ \\
3 & 4,3 & 64,8 & $-24,7$ \\
4 & 2,6 & 28,0 & $-15,8$ \\
5 & 11,0 & 44,4 & $-29,1$ \\
6 & 10,9 & 30,7 & $-14,4$ \\
7 & 04,8 & 15,5 & $-10,0$ \\
8 & 13,6 & 31,1 & $-16,2$ \\
9 & 1,1 & 32,4 & $-16,2$ \\
10 & 8,2 & 36,5 & $-21,6$ \\
11 & 14,0 & 34,7 & $-17,9$ \\
12 & 3,0 & 15,1 & $-14,2$ \\
13 & 4,1 & 13,5 & $-13,2$ \\
14 & 5,6 & 30,7 & $-17,3$ \\
15 & 1,9 & 37,5 & $-27,8$ \\
16 & 1,2 & 38,6 & $-27,7$ \\
17 & 3,4 & 34,8 & $-25,9$ \\
18 & 6,1 & 39,5 & $-28,8$ \\
19 & 6,3 & 21,2 & $-21,9$ \\
20 & 1,5 & 32,6 & $-28,5$ \\
\hline
\end{tabular}

Table 1. Mean displacements of the 20 steel rods in the 20132018 GPS-RTK measurements 


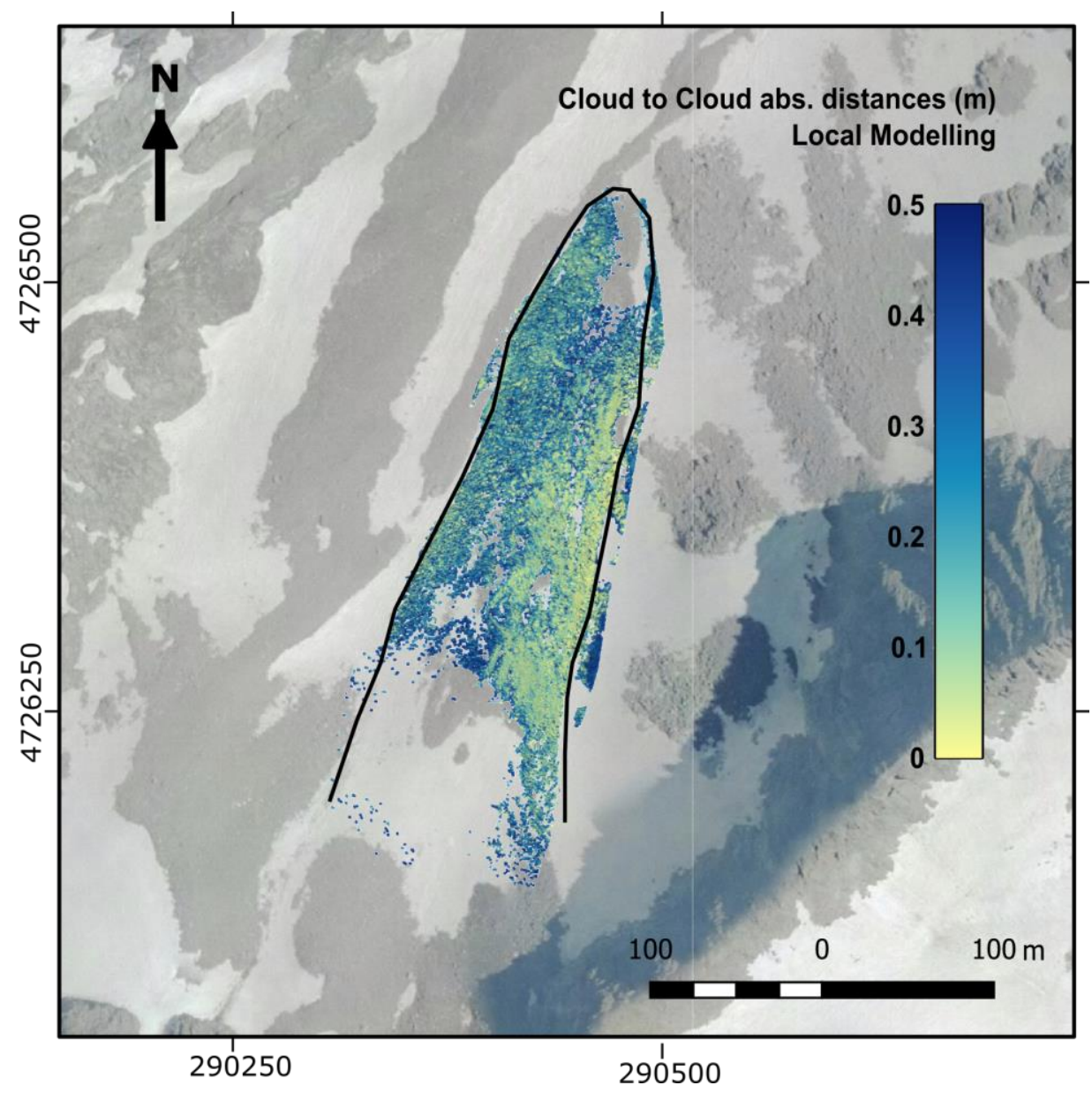

Figure 7. Cloud to Cloud with local modelling comparison between 2016 (reference) and 2017 (compared) point clouds of La Paúl Rock Glacier

Comparisons between point clouds (three scan campaigns, two years of comparisons) showed mean variations of $0.24 \mathrm{~m}$ (absolute values), with a standard deviation of $\pm 0.25 \mathrm{~m}$, in the central body of the rock glacier. In addition, the computed altimetric differences between clouds have been higher than the planimetric with a mean of $-0.015 \pm 0.21 \mathrm{~m}$ in the last two years. In accordance with the rod's displacements, primary dynamism was found in the western part of the glacier, whereas smallest in the eastern. Figure 7 shows the 2016-2017 Cloud to Cloud comparison. Notice that the rock glacier front could not be appropriately recorded during the 2016 scans so that no comparisons can be made.

\section{FINAL REMARKS}

The presence of frozen grounds is an indicator of the existence of permafrost-associated with other forms existing in its immediate environment related to ice, such as the La Paúl glacier, protalus lobes, debris lobes, or frost mounds (Serrano et al., 2001, González-García, 2014).

The GNSS-RTK and TLS measurements show that the rock glacier is active, with displacements of similar magnitude to other Pyrenean rock glaciers. The complex history of the rock glacier, with part of its north-western portion eroded during the LIA (Serrano and Martín-Moreno, 2018), exhibit its resilience capacity, in both ideal and marginal conditions, in the high temperate mountain. In this case, the La Paúl rock glacier is previous to the LIA, when the advance of the La Paúl glacier modified its eastern sector incorporating part of the rock glacier body to the lateral and frontal moraine.

To know in more detail the rates of change and deformation of the rock glacier (particularly in less active areas) is necessary to continue the measurements to obtain complete and precise data. Future efforts should be directed to an optimisation of the available resources (material and personnel), as well as an improvement in the planning of the surveys with the TLS equipment. Also, a more prolonged study, together with the combination of other geomatic techniques, will allow a better understanding of the behaviour of the La Paúl rock glacier and the relationships between the eroded and non-eroded sectors.

\section{ACKNOWLEDGEMENTS}

R+D+I Projects CGL2015-68144-R (Ministry of Economy and Competitiveness, FEDER) and Government of Extremadura (GR10071 FEDER).

\section{REFERENCES}

CloudCompare GPL software, Version 2.9. cloudcompare.org (December 2018). 
González García, M. 2014. La alta montaña periglaciar en el Pirineo Central español: procesos, formas y condiciones ambientales. Tesis doctoral, Universidad de Málaga.

López-Moreno, J.I., Nogués-Bravo, D., Chueca-Cía, J., JuliánAndrés, A. 2006. Change of topographic control on the extent of cirque glaciers since the Little Ice Age. Geophysical Research Letters, 33, L24505.

Lugon, R., Delaloyé, R., Serrano, E., Reynard, E., Lambiel, C., Gonzalez-Trueba, J.J. 2004. Permafrost and Little Ice Age relationships, Posets massif, Central Pyrenees, Spain. Permafrost and Periglaciar Processes 15, 207-220.

Sanjosé, J.J., Berenguer, F., Atkinson, A.D.J., De Matías, J., Serrano, E., Gómez-Ortiz, A., González-García, M., Rico, I. 2014. Geomatics techniques applied to glaciers, rock glaciers, and ice-patches in Spain (1991-2012). Geografiska Annaler: Series A, Physical Geography 96, 307-321.

Serrano, E., Agudo C., Martínez De Pisón, E. 1999. Rock glaciers in the Pyrenees. Permafrost and Periglacial Processes, 10, 101-106.

Serrano, E., Sanjosé, J.J., Agudo, C. 2006. Rock glacier dynamic in a marginal periglacial high mountain environment: flow, movement (1991-2000) and structure of the Argüalas rock glacier. Geomorphology 74, 285-296.

Serrano, E., Sanjosé, J.J., González Trueba, J.J. 2010. Rock glaciers dynamics in marginal periglaciar environments. Earth Surface Processes and Landforms 35 (11), 1302-1314.

Serrano, E., Martín Moreno, E. 2018. Surge glaciers during the Little Ice Age in the Pyrenees. Cuadernos de Investigación Geográfica 44 (1), 213-244. 